\title{
Influenza: environmental remodeling, population dynamics, and the need to understand networks
}

\section{María Paula Ortiz-Rodriguez and Luis Carlos Villamil-Jimenez*}

Epidemiology and Public Health Group, Universidad de La Salle, Bogotá, Colombia

*Correspondence: Iuvillamil@unisalle.edu.co

Edited by:

Rubén Bueno-Marí, University of Valencia, Spain

Reviewed by:

Jimmy Thomas Efird, Brody School of Medicine, USA

Keywords: hot spots, influenza, networks, disease dynamics, animal reservoirs

\section{NEW CHALLENGES FOR PUBLIC HEALTH}

Emergence of new pathogens has been the reality of the 21st century; the role of animal reservoirs and changes in human behaviors may be the main key factors for disease dynamics. Human population growth and territory expansion have lead to habitat sharing between human beings, domestic animals, wild animals, and their pathogens; bringing new opportunities for spill over. Risk assessment regarding the main factors associated with potential reassortment and transmission between species should get to a stage where the analysis of wildlife networks and interactions with domestic animals and human beings is well mapped. This last will allow an accurate prevention and control of hot spots of influenza transmission $(1,2)$.

The challenge for all public health professionals lies upon the integration of the analysis of environment, animal reservoirs, and human population as a whole and develop action plans accordingly to their interactions and not each of them separately $(3-5)$.

New animal production systems and human population dynamics have lead to different sources of infection that are not well understood. Although surveillance systems have improved considerably, the need for better communications and relations between environmental, health, and agricultural sectors is essential for a precise prevention of disease appearance and dispersal. Interdisciplinary and Intersectorial help becomes imperative when assessing the risk factors; such as human interactions with animals, wildlife contact with animal production systems, and environmental remodeling that contribute to disease emergence (6). In addition, the assessment of hot spots of influenza transmission should be the tool to map animal habitats that are at most risk of encounters with domestic animals that might serve as a mixing vessel and as the source of infection for humans $(7,8)$.

The emergence of influenza viruses is just one example of many diseases that have social and environmental factors that enhance their appearance and dispersal. The new strains that have emerged have social and environmental issues in common, which contribute to the appearance of new viruses, or at least, to the spillover between species; and it is here where the efforts should focus $(9,10)$.

\section{MULTICASUALITY, NETWORISS, AND DISEASE EMERGENCE - INTERDICIPLINARY CALL}

The close interaction between human beings and animals has determined many social behaviors, food availability, and diseases present nowadays $(11,12)$. When humans domesticated animals they started to be in close contact not only with the animals but also with the pathogens that they hosted. Some of these pathogens may have been of low pathogenicity in animals but after they acquired the ability to infect humans, they became pathogenic and even fatal for some hosts. This last is true only for some viruses that have the molecular characteristics that allow them to jump from one species to another, where genetic rearrangements and mutations result in new strains that infect more than one host from different species (13-15).

Spill over is the term used when a pathogen acquires the ability to jump from one species to another, allowing it to move to other habitats, and finally establish within a new niche (16). Is in these new niches where animal networks should be well assessed in order to prioritize the risks areas and animals involved in the dispersal and transmission of influenza virus for instance. As a consequence, when these interactions are understood the whole marketing systems and live bird markets' (LBMs) chains can be mapped and controlled $(17,18)$.

Understanding of the complete commerce chain; starting with the poultry farm and ending in the LBMs have been addressed by Martin and his colleagues. This sort of studies will be enriched if the contacts between wild and domestic animals are mapped to pinpoint the hot spots of possible niches where reassortment of the virus or an outbreak might take place $(17,19)$.

As it has been mentioned before, environmental interactions between animals, pathogens, and human beings play a crucial role in disease dynamics and its emergence or re-emergence. However, it is not only the environmental surroundings that determine the contact of this last three: social interactions, economic activities, and food related preferences and trade, but also have an impact and should be well assessed when conducting control and surveillance actions $(16,20)$. For influenza viruses, there are two main facts that should be well addressed. In the first place, the role of 
animal reservoirs such as migratory birds and bats and, in the second, the role of poultry farms, live animal markets, and how the animals are sold, transported, and maintained in these $(16,21,22)$.

Yet the above reasons give rise to new research and partnership opportunities that will need the participation of many disciplines. For instance, these new challenges will allow the accurate integration of the one health concept in the new approach to disease prevention.

\section{HOT SPOTS AND INFLUENZA TRANSMISSION - THE KEY FOR PREVENTION}

Network dynamics both in human beings and animals will determine the new pathogens for human populations $(23,24)$. Since climate change, population growth, and expansion are phenomena that are the reality for this century, human and animal health professionals will need to work from a population based perspective, but this time assessing the environment in which the interactions take place. Tracking the possible strategic spots in which intervention measures can be conducted. Diseases have unique characteristics, and although they may be well understood nowadays the lesson arises when even in the 21st century, we encounter disease threats that have complex behaviors and that are caused by multicasuality $(3,25)$.

For instance, it will be of much use to have complete knowledge of the health status of wild animals that live close to animal production systems and/or human living areas $(9,26)$. Consequently active surveillance should be coupled with a better understating about animal behavior, distance traveled by the birds and/or bats, nesting, and resting sites. It will be of much use to establish if the birds are migratory or resident, and if migratory map their networks in both living sites. Lastly, not only endangered species should be treated carefully but also included in this type of studies; furthermore, sampling should be accompanied by mapping and census $(27,28)$.

We will be achieving the correct introduction of the one health concept into the production systems, economic chains, and disease dynamics if we sum up all the relations that intervene in the dynamic of the disease. Finally interdisciplinary work will allow for a better and broader analysis of all the risk factors that put the health status of a country at risk. Finally we will not be prepared to respond to a pandemic event until the understanding of the interactions and influence of these in disease dynamics are incorporated into the prevention measures.

\section{REFERENCES}

1. Carrasco LR, Jit M, Chen MI, Lee VJ, Milne GJ, Cook AR. Trends in parameterization, economics and host behaviour in influenza pandemic modeling: a review and reporting protocol. Emerg Them Epidemiol (2013) 10:3. doi:10.1186/17427622-10-3

2. Patrick JR, Shaban RZ, FitzGerald G. Influenza: critique of the contemporary challenges for pandemic planning, prevention, control, and treatment in emergency health services. Aust Emerg Nurs J (2011) 14:108-14. doi:10.1016/j.aenj.2011.03.001

3. Murray KA, Daszak P. Human ecology in pathogenic landscapes: two hypotheses on how land use change drives viral emergence. Curr Opin Virol (2013) 3(1):79-83. doi:10.1016/j.coviro. 2013.01.006

4. Reperant LA, Kuiken T, Osterhaus AD. Adaptive pathways of zoonotic influenza viruses: from exposure to establishment in humans. Vaccine (2012) 30:4419-34. doi:10.1016/j.vaccine.2012.04.049

5. Smith J. Global Health and Sustainable Food Security: Why the Livestock Sectors of Developing Countries Matter. Global animal health conference on developing global animal health products to support food security and sustainability, Arlington, VA (2013).

6. Nishiura H, Hoye B, Klaassen M, Bauer S, Heesterbeek $H$. How to find natural reservoir hosts from endemic prevalence in a multi-host population: a case study of influenza in waterfowl. Epidemics (2009) 1:118-28. doi:10.1016/j.epidem. 2009.04.002

7. Taubenberger JK, Morens DM. Influenza: the once and future pandemic. Publ Health Rep (2010) 125(Suppl 3):16-26.

8. Vandegrift KJ, Sokolow SH, Daszak P, Kilpatrick AM. Ecology of avian influenza viruses in a changing world. Ann N Y Acad Sci (2010) 1195:113-28. doi:10.1111/j.1749-6632.2010.05451.x

9. Kitler ME, Gavinio P, Lavanchy D. Influenza and the work of the World Health Organization. Vaccine (2002) 20:S5-S14. doi:10.1016/ S0264-410X(02)00121-4

10. Loth L, Gilbert M, Wu J, Czarnecki C, Hidayat M, Xiao X. Identifying risk factors of highly pathogenic avian influenza (H5N1 subtype) in Indonesia. Prev Vet Med (2011) 102:50-8. doi:10.1016/j. prevetmed.2011.06.006

11. Alirol E, Getaz L, Stoll B, Chappuis F, Loutan L. Urbanisation and infectious diseases in a globalised world. Lancet (2011) 11(2):131-41. doi:10.1016/ S1473-3099(10)70223-1

12. Belshe BR. The origins of pandemic influenza lessons from the 1918 Virus. New Engl J Med (2005) 353:2. doi:10.1056/NEJMp058281
13. Chan JF, To KK, Tse H, Jin DY, Yuen KY. Interspecies transmission and emergence of novel viruses: lessons from bats and birds. Trends Microbiol (2013) 21:10. doi:10.1016/j.tim.2013.05.005

14. Christensen J, El Allaki F, Vallières A. Adapting a scenario tree model for freedom from disease as surveillance progresses: the Canadian notifiable avian influenza model. Prev Vet Med (2014) 114:132-44. doi:10.1016/j.prevetmed.2014. 01.023

15. Gaidet N, Ould ElMamy AB, Cappelle J, Caron A, Cumming GS, Grosbois V, et al. Investigating avian influenza infection hotspots in old-world shorebirds. PLoS One (2012) 7(9):e46049. doi:10. 1371/journal.pone.0046049

16. McMichael AJ, Powles JW, Butler CD, Uauy R. Food, livestock production, energy, climate change, and health. Lancet (2007) 370(9594):1253-63. doi: 10.1016/S0140-6736(07)61256-2

17. De Marco MA, Valentini A, Foni E, Savarese MC, Cotti C, Chiapponi C, et al. Is there a relation between genetic or social groups of mallard ducks and the circulation of low pathogenic avian influenza viruses? Vet Microbiol (2014) 170:418-24. doi:10.1016/j.vetmic.2014.03. 001

18. Oshitani H, Kamigaki T, Suzuki A. Major issues and challenges of influenza pandemic preparedness in developing countries. Emerg Infect Dis (2008) 14(6):875-80. doi:10.3201/eid1406. 070839

19. Slingenbergh J, Gilbert M, de Balogh K, Wint W. Ecological sources of zoonotic diseases. Rev Sci Tech Off Int Epiz (2004) 23(2):467-84.

20. Hamilton K. Global cooperation in countering emerging animal and zoonotic diseases. World Organization for Animal Health - OIE (2011).

21. Briand S, Mounts A, Chamberland M. Challenges of global surveillance during an influenza pandemic. Publ Health (2011) 125:247-56. doi:10. 1016/j.puhe.2010.12.007

22. Keeling MJ, Eames Ken TD. Networks and epidemic models. J R Soc Interface (2005) 2:295-307. doi:10.1098/rsif.2005.0051

23. Lavanchy D, Gavinio P. The importance of global influenza surveillance for the assessment of the impact of influenza. International Congress Series. Geneva: Department of Communicable Disease Surveillance and Response, World Health Organization (2001). 1219 p.

24. Woolhouse M, Gaunt E. Ecological Origins of Novel Human Pathogen. Crit Rev Microbiol (2007) 33(4):231-242. doi:10.1080/10408410701647560

25. McLeod A, et al. Economic and social impacts of avian influenza. FAO Emergency Centre for Transboundary Animal Diseases Operations (ECTAD) (2014).

26. Tong S, Zhu X, Li Y, Shi M, Zhang J, Bourgeois $M$, et al. New world bats harbor diverse influenza A viruses. PLoS Pathog (2013) 9(10):e1003657. doi:10.1371/journal.ppat.1003657

27. Fuller TL, Gilbert M, Martin V, Cappelle J, Hosseini P, Njabo KY, et al. Predicting hotspots for influenza virus reassortment. Emerg Infect Dis (2013) 19(4):581-8. doi:10.3201/eid1904. 120903

28. Martin V, Zhou X, Marshall E, Jia B, Fusheng G, FrancoDixon MA, et al. Risk-based surveillance 
for avian influenza control along poultry market chains in South China: the value of social network analysis. Prev Vet Med (2011) 102:196-205. doi:10.1016/j.prevetmed.2011.07.007

Conflict of Interest Statement: The authors declare that the research was conducted in the absence of any commercial or financial relationships that could be construed as a potential conflict of interest.
Received: 19 May 2014; paper pending published: 21 July 2014; accepted: 06 September 2014; published online: 29 September 2014.

Citation: Ortiz-Rodriguez MP and Villamil-Jimenez LC (2014) Influenza: environmental remodeling, population dynamics, and the need to understand networks. Front. Public Health 2:153. doi: 10.3389/fpubh.2014.00153

This article was submitted to Epidemiology, a section of the journal Frontiers in Public Health.
Copyright (C) 2014 Ortiz-Rodriguez and VillamilJimenez. This is an open-access article distributed under the terms of the Creative Commons Attribution License (CC BY). The use, distribution or reproduction in other forums is permitted, provided the original author(s) or licensor are credited and that the original publication in this journal is cited, in accordance with accepted academic practice. No use, distribution or reproduction is permitted which does not comply with these terms. 